\title{
Skeletal Variations of the Seventh Cervical Vertebrae in the Mouse with Special Reference to the Foramina Transversaria and the Accessory Foramina
}

\author{
By \\ M. Y. KIDA, D. R. JOHNSON* and P. O'HIGGINS** \\ Department of Anatomy, Sapporo Medical College, Sapporo, Japan \\ *Morphometrics Laboratory, Department of Anatomy, University of Leeds, UK \\ **Department of Anatomy and Human Biology, The University of Western Australia, Nedlands 6009, Western Australia
}

- Received for Publication, March 18, $1992-$

\begin{abstract}
Key Words: Skeletal variation, Seventh cervical vertebra, Foramen transversarium, Heredity, Mouse
Summary: The formation of foramina tansversaria in the seventh cervical vertebra of CBA and C57BL mice and their offspring is found to behave as if it is determined by a single semi-dominant gene.

The accessory foramina of Weber (1950) are investigated in the same material. These foramina are classified into two types and their heredity is evaluated.
\end{abstract}

In a series of recent papers Johnson and O'Higgins have developed alternative methods for evaluating the differences in bone shape using Fourier analysis (Johnson et al, 1985; O'Higgins \& Johnson, 1988, Johnson, O'Higgins, McAndrew and Kida, in press). In the course of those studies we noticed some minor variations of mouse cervical vertebra, which are not described in Grüneberg's classic "The pathology of development" (Grüneberg, 1963). Our studies on Grüneberg's material have placed us in a unique situation, and we have taken this opportunity of making the record of these skeletal variations as accurate as possible.

\section{Materials and Methods}

The cervical vertebrae used in this study were from two inbred strains (CBA and C57BL), the F1 between them $(\mathrm{CB}$ and $\mathrm{BC})$ and the back cross $\mathrm{CBA} / \mathrm{CB}$, from the Grüneberg collection of mouse skeletons from the British Museum of Natural History, on permanent loan to one of us (D. R. Johnson). Details of the numbers of each sample are given in

Table 1. Number of mice observed in each sample.

\begin{tabular}{lccccc} 
& CBA & C57BL & CB & BC & CBA/CB \\
\hline Male & 30 & 25 & 28 & 25 & 25 \\
Female & 23 & 27 & 24 & 27 & 27 \\
Total & 53 & 52 & 52 & 52 & 52 \\
\hline
\end{tabular}

Table 1. The C1-T2 vertebrae were examined under a dissecting microscope and incidences of foramina transversaria and other foramina were recorded.

\section{Results}

\section{Foramina transversaria in the seventh cervical} vertebra

Eight cases of complete formation and twentythree cases of incomplete formation of the foramina transversaria (FTI) were observed in the 261 seventh cervical vertebrae of the five groups. A closer observation revealed ninety-seven cases of rudimentary formation of the foramina. Here "incomplete" resembles the gutter formation described in Grüneberg (1950). "Rudimentary" indicates the formation of a shallow groove.

These variations clearly belong to the same trait, the formation of foramina transversaria. In order to summarise our observations four phenotypic categories were defined: perfectly formed (P), imperfectly formed (I), rudimentary (R) and not manifested (N) (Table 2). Sex differences and laterality were not detectable in the five groups observed.

Differences in incidence were not significant between CBA, CB and CBA/CB at the 5\% level, but were significant at the $1 \%$ level between $\mathrm{C} 57 \mathrm{BL}$ and the other groups.

In the cross between CBA and C57BL the incidence of foramina transversaria is consistent with 
Table 2. Incidence of formation of the foramen transversarium in the seventh cervical vertebra.

\begin{tabular}{llllrrrrrrrrr} 
& & \multicolumn{1}{c}{ Grade of manifestation of the formation* } \\
& PP & PI & PR & PN & II & IR & IN & RR & RN & (subtotal) & NN & Total \\
\hline CBA & 0 & 1 & 2 & 0 & 1 & 4 & 8 & 6 & 16 & $(38)$ & 15 & 53 \\
C57BL & 0 & 0 & 0 & 0 & 0 & 0 & 1 & 0 & 1 & $(2)$ & 50 & 52 \\
CB & 0 & 1 & 1 & 1 & 0 & 2 & 0 & 16 & 15 & $(35)$ & 17 & 52 \\
BC & 0 & 0 & 0 & 1 & 0 & 1 & 0 & 4 & 14 & $(20)$ & 32 & 52 \\
CBA/CB & 0 & 0 & 1 & 0 & 0 & 2 & 2 & 12 & 20 & $(37)$ & 15 & 52 \\
\hline
\end{tabular}

*: The conditions of both sides are expressed by double letters.

Table 3. The foramen transversarium in the seventh cervical vertebra: Observation and expectation for the cross between CBA and CB.

\begin{tabular}{lllllllllllll} 
& PP & PI & PR & PN & II & IR & IN & RR & RN & (subtotal) & NN & Total \\
\hline Obs. & 0 & 0 & 1 & 0 & 0 & 2 & 2 & 12 & 20 & $(37)$ & 15 & 52 \\
Exp. & 0.0 & 1.0 & 1.5 & 0.0 & 0.5 & 3.0 & 3.9 & 10.9 & 15.3 & $(36.1)$ & 15.9 & 52 \\
\hline
\end{tabular}

the hypothesis that it is controlled by a single, semidominant gene homozygous in the CBA stock where manifestation is highest and heterozygous in the F1. The observed and expected values for the incidence of foramina transversaria in the backcross (CBA $\times$ CB) shown in Table 3 are in good agreement with this hypothesis $\left(\chi^{2}=3.57\right.$, d.f. $=9$, not significant at the level of $5 \%$ ).

With regard to the formation of foramina transversaria in the seventh cervical vertebra, the dystopia caudalis of the tuberculum anterius is implicated by Grüneberg (1950a). However in only two cases did FTI coexist with dystopia.

\section{Medial opening of foramina transversaria imperfecta}

Two cases of medial opening of foramina transversaria imperfecta of the sixth cervical vertebra were observed in the fifty-two C57BL animals studied by us. Grüneberg (1950a) did not observe this opening in his sample of fifty-two animals of C57BL stock.

\section{Distinct types of foramina in the seventh cervical vertebra}

Two types of small accessory foramina were observed in the seventh cervical vertebra (Fig. 1),

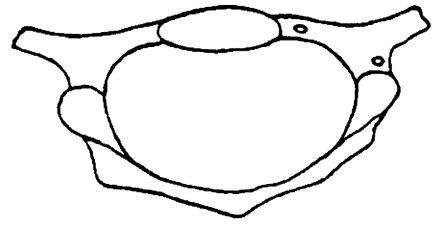

Fig. 1 The seventh cervical vertebra of CBA male (94 days old) with two accessory foramina of the lateral and medial type on the right side.

one in the lateral side of the base of transverse process (on the lateral side of the superior vertebral notch), and the other more medially. These occurred as frank foramina, pinpoints or dimples. The occurrences and distributions of these foramina in the five groups are tabulated in Table 4.

The incidence of the lateral type was significantly greater in $\mathrm{BC}$ than in the other groups $(\mathrm{P}<2 \%)$. The incidence of the medial type in $\mathrm{C} 57 \mathrm{BL}$ was significantly different from that in the others $(\mathrm{P}<2 \%)$ with the exception of $\mathrm{CB}$ (ie. there was a significant difference between the parental stocks). The difference between $\mathrm{CB}$ and $\mathrm{BC}$ was not significant at the $5 \%$ level. The observed and expected values for the incidence of the medial foramen in the backcross

Table 4. Incidence of the two kinds of accessory foramina observed in the seventh cervical vertebra.

\begin{tabular}{|c|c|c|c|c|c|c|c|c|c|c|}
\hline & \multicolumn{5}{|c|}{ Lateral type } & \multicolumn{5}{|c|}{ Medial type } \\
\hline & Bilateral & Right & Left & Total & $\%$ & Bilateral & Right & Left & Total & $\%$ \\
\hline $\mathrm{CBA}$ & 0 & 7 & 7 & 14 & 26.4 & 0 & 5 & 2 & 7 & 13.2 \\
\hline C57BL & 0 & 8 & 4 & 12 & 23.1 & 0 & 0 & 0 & 0 & 0.0 \\
\hline $\mathrm{CB}$ & 5 & 7 & 7 & 19 & 36.5 & 0 & 1 & 2 & 3 & 5.8 \\
\hline $\mathrm{BC}$ & 13 & 9 & 10 & 32 & 61.5 & 0 & 5 & 1 & 6 & 11.5 \\
\hline $\mathrm{CBA} / \mathrm{CB}$ & 5 & 5 & 10) & 20 & 38.5 & 0 & 1 & 4 & 5 & 9.6 \\
\hline
\end{tabular}


Table 5. The medial accessory foramen in the seventh cervical vertebra: Observation and expectation for the cross between $\mathrm{CBA}$ and $\mathrm{CB}$.

\begin{tabular}{lccccc} 
& Bilateral & Right & Left & Absent & Total \\
\hline Observed value & 0 & 1 & 4 & 47 & 52 \\
Expected value & 0 & 3.0 & 2.0 & 47.1 & 52.1 \\
\hline
\end{tabular}

$(\mathrm{CBA} \times \mathrm{CB})$ shown in Table 5 again support the hypothesis of a single semi-dominant gene $\left(\chi^{2}=3.33\right.$, d.f. $=3$, no significant difference between observed and expected at the $5 \%$ level).

\section{Discussion}

In the mouse the foramina transversaria are usually formed in the first to sixth cervical vertebrae. These foramina are likely to be imperfectly formed in some stocks as in man where the foramina are often closed by a ligament. Grüneberg studied this trait widely, and concluded that the foramina transversaria imperfecta behave as if governed by a single semi-dominant gene (Grüneberg, 1950a).

In the same paper he also described the formation of foramina transversaria in the seventh cervical vertebra (CVII) as follows: "Four out of seventy-one mice in the Strong CBA pure line showed a dystopia of the tuberculum anterius (tuberculum anterius accessorius) in a caudal direction, that is, on to CVII. The accessory tuberculum anterius of the two animals has gained double contact with CVII in such a way as to enclose a perfectly normal-sized foramen transversarium. In the other two animals the tuberculum is attached to CVII at one point only; it thus forms the better part of a foramen transversarium. This creates a picture very similar to the foramina transversaria imperfecta condition in C57BL. The resemblance is, however, only superficial. In foramina transversaria imperfecta, a foramen which is part of the normal anatomy is incomplete; in the case under discussion a foramen not normally present is formed, but this process does not always proceed to perfection".

Grüneberg (1950a) explained the formation of foramina transversaria in the CVII in relation to a dystopia of the tuberculum anterius. However, only two cases of coexistence of these traits are observed in this study. This seems to contradict his explanation since the two traits seem to be independent of each other in the cross between CBA and C57BL.

The data presented here on the genetic control of the formation of foramina transversaria in the CVII are compatible with the assumption that the trait in the cross between CBA and C57BL behaves like a single-gene difference with semi-dominance of the trait.

Our finding that the formation of foramina transversaria in CVII was higher in CB (Table 2) presumably reflects the effects of maternal physiology (a common finding in the study of minor skeletal variation, Grüneberg, 1963).

Grüneberg (1950a) reported that the medial opening had not been observed in C57BL, was common in the $\mathrm{F} 1$ between $\mathrm{C} 57 \mathrm{BL}$ and Strong $\mathrm{A}$ and particularly in the backcross to Strong A, less common in the $\mathrm{F} 2$ and least in the backcross to C57BL. He also said that this situation was consistent with the assumption that Strong A carried a semidominant gene (or genes). In this study, this trait is observed in C57BL stock itself.

A description of the medial and lateral accessory foramina was given by Weber (1950). He described them in the fifth and sixth cervical vertebrae but did not discriminate between them by location. He also described accessory foramina in CVII, but apparently the lateral type only: "This accessory foramen occurred in all wild populations sampled, but the frequency differs considerably from population to population". He concluded that it seemed most likely that the differences between populations have a genetical basis.

The accessory foramina of the lateral and medial types in the CVII have, to our knowledge, not been reported in CBA and $\mathrm{C} 57 \mathrm{BL}$. The incidence of the lateral type in $\mathrm{BC}$ is significantly different from that in the others. This could also suggest the effect of maternal environment. However, the genetic basis of this feature is unknown.

On the other hand, the incidence of the medial type shows a significant difference between the parental stocks. In addition, on the assumption that this trait behaves like a semi-dominant feature and is controlled by a single-gene, the observed and expected values agree with each other, although the penetrance is low (Table 4).

\section{Acknowledgements}

We are deeply grateful to Mr. S. Paxton, Department of Anatomy, University of Leeds and Professor Y. Dodo, Department of Anatomy Sapporo Medical College for their useful advice and help.

\section{References}

1) Grüneberg. H.: Genetical studies on the skeleton of the mouse I. Minor variations of the vertebral column. J. Genetics 50: $112-141,1950 \mathrm{a}$.

2) Gruncberg. H.: Genctical studies on the skeleton of the mouse Il. Undulated and its 'modifiers'. J. Genctics 50: 
142-173, 1950b.

3) Grüneberg, H.: The pathology of development. 255-259pp., Blackwell, Oxford, 1963.

4) Johnson, D. R., O'Higgins, P., McAndrew, T. J., Adams, L. M. \& Flinn, R. M.: Measurement of biological shape: a general method applied to mouse vertebrae. J. Embryol. exp. Morph. 90: 363-377, 1985.

5) Johnson, D. R., O’Higgins, P., McAndrew, T. J. \& Kida M. Y.: The inheritance of vertebral shape in the mouse I: A study using Fourier analysis to examine patterns of inheritance in the morphology of cervical and upper thoracic vertebrac. J. Anat. (in press)

6) O'Higgins, P. and Johnson, D. R.: The quantitative description and comparison of biological forms. CRC Critical Reviews in Anatomical Sciences I: 149-170, 1988.

7) Weber, W.: Genetical studies on the skeleton of the mouse III. Skeletal variation in wild populations. J. Genetics 50: 174-178, 1950. 